\title{
PENENTUAN PREMI DARI ASURANSI KONTINGENSI (CONTINGENT INSURANCE)
}

\author{
STEFI AMALIA FITRI \\ Program Studi Matematika, \\ Fakultas Matematika dan Ilmu Pengetahuan Alam, Universitas Andalas, \\ Kampus UNAND Limau Manis Padang, Indonesia, \\ stefiamaliafitri27@gmail.com
}

\begin{abstract}
Abstrak. Asuransi kontingensi (contingent insurance) adalah asuransi jiwa bersama dimana pembayaran uang santunan dikaitkan dengan urutan kematian individu meninggal dunia pertama atau meninggal dunia kedua sesuai dengan surat perjanjian (polis). Surat perjanjian (polis) pada asuransi kontingensi berakhir jika terjadi peristiwa salah satu tertanggung meninggal dunia sesuai dengan urutan kematian pada polis, dalam hal tersebut klaim terjadi atau jika urutan kematian bertentangan dengan polis, maka santunan tidak dibayarkan pada ahli waris. Dengan memperhatikan urutan kematian peserta asuransi jiwa bersama, maka premi dari asuransi kontingensi dapat ditentukan dengan memperhatikan banyak peserta, jenis asuransi yang diikuti oleh tertanggung yaitu asuransi seumur hidup atau asuransi berjangka.
\end{abstract}

Kata Kunci: Asuransi jiwa bersama, asuransi kontingensi, santunan, premi, polis

\section{Pendahuluan}

Asuransi jiwa yang berkembang di Indonesia ada dua macam, yaitu asuransi jiwa perorangan (single life) dan asuransi jiwa bersama (multi life). Perbedaan antara asuransi perorangan dengan asuransi jiwa bersama terletak pada peserta yang mengikuti asuransi tersebut. Pada asuransi jiwa perorangan, perusahaan asuransi memberikan perlindungan untuk satu orang, sedangkan jumlah tertanggung pada asuransi jiwa bersama lebih dari satu orang. Salah satu produk asuransi jiwa bersama adalah asuransi status gabungan untuk asuransi bersama (joint life insurance).

Pada perhitungan premi asuransi bersama, pembayaran uang santunan tidak dikaitkan dengan urutan kematian individu tersebut terjadi. Tetapi bagaimana bentuk perhitungan premi jika pembayaran uang santunan dikaitkan dengan urutan kematian. Pada paper ini penulis akan membahas perhitungan premi dimana pembayaran uang santunan dikaitkan dengan urutan kematian yang dikenal dengan asuransi kontingensi (contingent insurance).

\section{Asuransi Kontingensi (Contingent Insurance)}

Asuransi kontingensi (contingent insurance) adalah asuransi bersama dimana pembayaran uang santunan dikaitkan dengan urutan kematian individu meninggal dunia 
pertama atau meninggal dunia kedua sesuai dengan surat perjanjian (polis), jika ini tidak terjadi, maka santunan tidak dibayarkan pada ahli waris [5].

Untuk penentuan premi dari asuransi kontingensi, berikut akan dibahas tentang simbol komutasi, peluang dan anuitas yang nantik digunakan dalam asuransi kontingensi. Simbol komutasi adalah simbol yang digunakan untuk mempermudah perhitungan dalam tabel mortalitas [3].

Untuk tertanggung sebanyak dua orang yang berusia $x$ dan $y$ tahun maka

$$
\begin{aligned}
D_{x y} & =v^{\frac{x+y}{2}} l_{x y}, \\
N_{x y} & =\sum_{t=0}^{\omega} D_{x+t: y+t}=D_{x y}+D_{x+1: y+1}+\cdots+D_{\omega \omega}, \\
C_{x y}^{1} & =v^{\frac{x+y}{2}+1} d_{x} l_{y+1 / 2}, \\
M_{x y}^{1} & =\sum_{t=0}^{\omega} C_{x+t: y+t}^{1}=C_{x y}^{1}+C_{x+1: y+1}^{1}+\cdots+C_{\omega \omega}^{1} .
\end{aligned}
$$

Untuk tertanggung sebanyak tiga orang yang berusia $x, y$ dan $z$ tahun maka

$$
\begin{aligned}
& D_{x y z}=v^{\frac{x+y+z}{3}} l_{x y z} \\
& N_{x y z}=\sum_{t=0}^{\omega} D_{x+t: y+t: z+t}=D_{x y z}+D_{x+1: y+1: z+1}+\cdots+D_{\omega \omega \omega}, \\
& C_{x y z}^{1}=v^{\frac{x+y+z}{3}+1} d_{x} l_{y+1 / 2: z+1 / 2} \\
& M_{x y z}^{1}=\sum_{t=0}^{\omega} C_{x+t: y+t: z+t}^{1}=C_{x y z}^{1}+C_{x+1: y+1: z+1}^{1}+\cdots+C_{\omega \omega \omega}^{1},
\end{aligned}
$$

dimana $v$ adalah nilai sekarang dari pembayaran sebesar 1 yang dilakukan satu tahun kemudian. Secara matematis dinyatakan sebagai [2]:

$$
v=\frac{1}{1+i}=(1+i)^{-1} .
$$

Pada umumnya sebuah kelompok asuransi yang terlibat tidak memiliki usia yang sama [3], maka peluang kontingensinya dapat dilihat dalam beberapa kasus berikut.

- Kasus 1. Terdapat dua orang yang berusia $x$ dan $y$.

Peluang bahwa $(x)$ akan meninggal dunia sebelum $(y)$ dan dalam waktu $n$ tahun, dengan kata lain bahwa $(x)$ meninggal pertama, dapat ditulis sebagai berikut [3].

$$
{ }_{n} q_{x y}^{1}=\frac{1}{l_{x} l_{y}} \sum_{t=0}^{n-1} d_{x+t} l_{y+t+1 / 2} .
$$

Peluang bahwa $(x)$ akan meninggal dunia kedua dalam $n$ tahun, dapat ditulis sebagai berikut

$$
{ }_{n} q_{x y}^{2}={ }_{n} q_{x}-{ }_{n} q_{x y}^{1} .
$$

Peluang bahwa $(x)$ akan meninggal dunia kedua dalam $n+1$ tahun adalah

$$
{ }_{n}\left|q_{x y}^{2}={ }_{n}\right| q_{x}-{ }_{n} \mid q_{x y}^{1} .
$$


- Kasus 2. Terdapat tiga orang berusia $x, y$ dan $z$.

Peluang bahwa $(x)$ akan meninggal dunia dalam $n$ tahun sebelum $(y)$ dan $(z)$, dapat ditulis sebagai berikut

$$
{ }_{n} q_{x y z}^{1}=\frac{1}{l_{x} l_{y} l_{z}} \sum_{t=0}^{n-1} d_{x+t} l_{y+t+1 / 2} l_{z+t+1 / 2} .
$$

Peluang bahwa (x) meninggal dunia kedua adalah

$$
{ }_{n} q_{x y z}^{2}={ }_{n} q_{x y}^{1}+{ }_{n} q_{x z}^{1}-2{ }_{n} q_{x y z}^{1} .
$$

Sedangkan peluang $(x)$ meninggal dunia ketiga adalah

$$
{ }_{n} q_{x y z}^{3}={ }_{n} q_{x}-{ }_{n} q_{x y}^{1}-{ }_{n} q_{x z}^{1}+{ }_{n} q_{x y z}^{1} .
$$

Anuitas hidup secara umum terbagi menjadi dua macam, yaitu

(1) Anuitas Seumur Hidup, yaitu pembayaran berkala selama orang tersebut masih hidup.

(2) Anuitas Berjangka, yaitu pembayaran berkala dalam jangka waktu tertentu, misalkan $n$ tahun.

Pembayaran anuitas biasanya dilakukan di tiap awal jangka waktu pembayaran atau di tiap akhir jangka waktu pembayaran [1].

- Anuitas hidup perorangan untuk seseorang berusia $x$ tahun [4]

- Anuitas awal untuk asuransi seumur hidup

$$
\ddot{a}_{x}=\frac{N_{x}}{D_{x}}
$$

- Anuitas akhir untuk asuransi seumur hidup

$$
a_{x}=\frac{N_{x+1}}{D_{x}}
$$

- Anuitas awal untuk asuransi berjangka

$$
\ddot{a}_{x: \bar{n} \mid}=\frac{N_{x}-N_{x+n}}{D_{x}}
$$

- Anuitas akhir untuk asuransi berjangka

$$
a_{x: \bar{n} \mid}=\frac{N_{x+1}-N_{x+n+1}}{D_{x}}
$$

- Anuitas hidup bersama untuk dua orang tertanggung yang berusia $x$ dan $y$ tahun [3]

- Anuitas awal untuk asuransi seumur hidup

$$
\ddot{a}_{x y}=\frac{N_{x y}}{D_{x y}}
$$

- Anuitas akhir untuk asuransi seumur hidup

$$
a_{x y}=\frac{N_{x+1: y+1}}{D_{x y}}
$$


- Anuitas awal untuk asuransi berjangka

$$
\ddot{a}_{x y: \bar{n} \mid}=\frac{N_{x y}-N_{x+n: y+n}}{D_{x y}}
$$

- Anuitas akhir untuk asuransi berjangka

$$
a_{x y: \bar{n} \mid}=\frac{N_{x+1: y+1}-N_{x+n+1: y+n+1}}{D_{x y}}
$$

Setelah menentukan simbol komutasi, peluang dan anuitas yang digunakan dalam asuransi kontingensi, maka dapat ditentukan premi tunggal bersih pada Asuransi Kontingensi Seumur Hidup dan Asuransi Kontingensi Berjangka, serta premi tahunan dari Asuransi Kontingensi Seumur Hidup dan Asuransi Kontingensi Berjangka sebagai berikut.

Premi tunggal bersih adalah pembayaran premi asuransi yang dilakukan pada waktu kontrak asuransi disetujui, selanjutnya tidak dilakukan pembayaran lagi. Sementara premi tahunan adalah premi yang dibayarkan pada setiap awal permulaan tahun oleh peserta asuransi. Sebuah kontrak asuransi kontingensi dapat diakhiri jika salah satu dari dua hal berikut terjadi. Pertama dengan terjadinya peristiwa diasuransikan, dalam hal tersebut klaim terjadi. Kedua apabila urutan kematian berbeda dengan urutan kematian yang diasuransikan, dalam hal ini kontrak berakhir.

(1) Premi Tunggal Bersih pada Asuransi Kontingensi Seumur Hidup.

- Kasus 1. Terdapat dua orang tertanggung dengan usia $x$ dan $y$. Misalkan uang santunan sebesar Rp. 1,- dibayarkan pada akhir tahun kematian dari $(x)$, dengan ketentuan bahwa $(x)$ meninggal sebelum $(y)$ atau dengan kata lain $(x)$ meninggal pertama, dinotasikan dengan $A_{x y}^{1}$, maka

$$
A_{x y}^{1}=\frac{M_{x y}^{1}}{D_{x y}} .
$$

Sedangkan untuk ketentuan $(x)$ meninggal kedua, dinotasikan dengan $A_{x y}^{2}$, maka

$$
A_{x y}^{2}=A_{x}-A_{x y}^{1}
$$

- Kasus 2. Terdapat tiga orang tertanggung dengan usia $x, y$ dan $z$.

Misalkan uang santunan sebesar $R p .1$,- dibayarkan pada akhir tahun kematian dari $(x)$, dengan ketentuan bahwa $(x)$ meninggal sebelum $(y)$ dan $(z)$, dinotasikan dengan $A_{x y z}^{1}$ maka

$$
A_{x y z}^{1}=\frac{M_{x y z}^{1}}{D_{x y z}} .
$$

Sedangkan untuk ketentuan $(x)$ meninggal kedua, dinotasikan dengan $A_{x y z}^{2}$, maka

$$
A_{x y z}^{2}=A_{x y}^{1}+A_{x z}^{1}-2 \cdot A_{x y z}^{1} .
$$


Dan untuk ketentuan $(x)$ meninggal ketiga, dinotasikan dengan $A_{x y z}^{3}$, maka

$$
A_{x y z}^{3}=A_{x}-A_{x y}^{1}-A_{x z}^{1}+A_{x y z}^{1} .
$$

\section{(2) Premi Tunggal Bersih pada Asuransi Kontingensi Berjangka}

- Kasus 1. Terdapat dua orang tertanggung dengan usia $x$ dan $y$.

Misalkan uang santunan sebesar Rp. 1,- dibayarkan pada akhir tahun kematian dari $(x)$, dengan ketentuan bahwa $(x)$ meninggal sebelum $(y)$ atau dengan kata lain $(x)$ meninggal pertama, dinotasikan dengan $A_{x y: \bar{n} \mid}^{1}$, maka

$$
A_{x y: \overline{n \mid}}^{1}=\frac{M_{x y}^{1}-M_{x+n: y+n}}{D_{x y}} .
$$

Sedangkan untuk ketentuan $(x)$ meninggal kedua, dinotasikan dengan $A_{x y: \bar{n} \mid}^{2}$, maka

$$
A_{x y: \bar{n} \mid}^{2}=A_{x: \bar{n} \mid}-A_{x y: \overline{n \mid}}^{1} .
$$

- Kasus 2. Terdapat tiga orang tertanggung dengan usia $x, y$ dan $z$.

Misalkan uang santunan sebesar $R p .1,-$ dibayarkan pada akhir tahun kematian dari $(x)$, dengan ketentuan bahwa $(x)$ meninggal sebelum $(y)$ dan $(z)$, dinotasikan dengan $A_{x y z: \bar{n} \mid}^{1}$, maka

$$
A_{x y z: \bar{n} \mid}^{1}=\frac{M_{x y z}^{1}-M_{x+n: y+n: z+n}}{D_{x y z}} .
$$

Sedangkan untuk ketentuan $(x)$ meninggal kedua, dinotasikan dengan $A_{x y z: \bar{n} \mid}^{2}$, maka

$$
A_{x y z: \overline{n \mid}}^{2}=A_{x y: \overline{n \mid}}^{1}+A_{x z: \bar{n} \mid}^{1}-2 \cdot A_{x y z: \bar{n} \mid}^{1} .
$$

Dan untuk ketentuan $(x)$ meninggal ketiga, dinotasikan dengan $A_{x y z: \bar{n} \mid}^{3}$, maka

$$
A_{x y z: \bar{n} \mid}^{3}=A_{x: \bar{n} \mid}-A_{x y: \bar{n} \mid}^{1}-A_{x z: \overline{n \mid}}^{1}+A_{x y z: \bar{n} \mid}^{1} .
$$

\section{(3) Premi Tahunan dari Asuransi Kontingensi Seumur Hidup}

- Kasus 1. Terdapat dua orang tertanggung dengan usia $x$ dan $y$. Misalkan dibayarkan uang santunan sebesar $R p .1,-$ pada akhir tahun kematian dari $(x)$, dengan ketentuan bahwa $(x)$ meninggal sebelum $(y)$, maka premi tahunannya adalah

$$
P_{x y}^{1}=\frac{A_{x y}^{1}}{\ddot{a}_{x y}}=\frac{M_{x y}^{1}}{N_{x y}} .
$$

Sedangkan untuk ketentuan $(x)$ meninggal kedua, maka premi tahunannya adalah

$$
P_{x y}=\frac{A_{x y}^{2}}{\ddot{a}_{x}}
$$


- Kasus 2. Terdapat tiga orang tertanggung dengan usia $x, y$ dan $z$.

Misalkan dibayarkan uang santunan sebesar $R p$. 1,- pada akhir tahun kematian dari $(x)$, dengan ketentuan

- Jika $(x)$ meninggal sebelum $(y)$ dan $(z)$, maka premi tahunannya adalah

$$
P_{x y z}^{1}=\frac{A_{x y z}^{1}}{\ddot{a}_{x y z}}=\frac{M_{x y z}^{1}}{N_{x y z}} .
$$

- Jika $(x)$ meninggal kedua, maka premi tahunannya adalah

* Saat $(y)$ meninggal dunia pertama,

$$
P_{x y z}=\frac{A_{x y z}^{2}}{\ddot{a}_{x z}} .
$$

* Saat $(z)$ meninggal dunia pertama,

$$
P_{x y z}=\frac{A_{x y z}^{2}}{\ddot{a}_{x y}} .
$$

- Jika $(x)$ meninggal ketiga, maka premi tahunannya adalah

$$
P_{x y z}=\frac{A_{x y z}^{3}}{\ddot{a}_{x}} .
$$

\section{(4) Premi Tahunan dari Asuransi Kontingensi Berjangka}

- Kasus 1. Terdapat dua orang tertanggung dengan usia $x$ dan $y$. Misalkan dibayarkan uang santunan sebesar $R p$. 1,- pada akhir tahun kematian dari $(x)$, dengan ketentuan bahwa $(x)$ meninggal sebelum $(y)$, maka premi tahunannya adalah

$$
P_{x y: \overline{n \mid}}^{1}=\frac{A_{x y: \bar{n}}^{1}}{\ddot{a}_{x y: \bar{n} \mid}}=\frac{M_{x y}^{1}-M_{x+n: y+n}^{1}}{N_{x y}-N_{x+n: y+n}} .
$$

Sedangkan untuk ketentuan $(x)$ meninggal kedua, maka premi tahunannya adalah

$$
P_{x y: \overline{n \mid}}=\frac{A_{x y: \overline{n \mid}}^{2}}{\ddot{a}_{x: \bar{n} \mid}} .
$$

- Kasus 2. Terdapat tiga orang tertanggung dengan usia $x, y$ dan $z$.

Misalkan dibayarkan uang santunan sebesar $R p$. 1,- pada akhir tahun kematian dari $(x)$, dengan ketentuan

- Jika $(x)$ meninggal sebelum $(y)$ dan $(z)$, maka premi tahunannya adalah

$$
P_{x y z: \bar{n} \mid}^{1}=\frac{A_{x y z: \bar{n} \mid}^{1}}{\ddot{a}_{x y z: n \mid}}=\frac{M_{x y z}^{1}-M_{x+n: y+n: z+n}^{1}}{N_{x y z}-N_{x+n: y+n: z+n}} .
$$

- Jika (x) meninggal kedua, maka premi tahunannya adalah 
* Saat $(y)$ meninggal dunia pertama,

$$
P_{x y z: \bar{n} \mid}=\frac{A_{x y z: \bar{n} \mid}^{2}}{\ddot{a}_{x z: \bar{n} \mid}} .
$$

* Saat (z) meninggal dunia pertama,

$$
P_{x y z: \overline{n \mid}}=\frac{A_{x y z: \bar{n} \mid}^{2}}{\ddot{a}_{x y: \overline{1}}} .
$$

- Jika $(x)$ meninggal ketiga, maka premi tahunannya adalah

$$
P_{x y z: \bar{n} \mid}=\frac{A_{x y z: \bar{n} \mid}^{3}}{\ddot{a}_{x: \overline{n \mid}}} .
$$

\section{Contoh Aplikasi untuk Asuransi Kontingensi}

Pada saat ini bahaya kecelakaan, sakit dan kematian tidak diperkirakan kapan datangnya. Untuk menghindari atau paling tidak meminimalkan resiko yang mungkin terjadi, setiap orang membutuhkan sesuatu yang dapat menjamin kehidupan orang-orang yang ia tinggalkan apabila sesuatu yang tidak diinginkan terjadi padanya. Menghindari hal itu Arief (suami) yang berusia 40 tahun dan Fitri (istri) yang berusia 35 tahun mengikuti program asuransi kontingensi dengan harapan santunan yang akan diterima ahli waris ketika Arief dan Fitri meninggal dunia adalah Rp. 100.000.000. Maka akan ditentukan besar premi tunggal dan premi tahunan yang harus dibayarkan Arief meninggal dunia pertama dan Arief meninggal dunia kedua dimana mereka mengikuti asuransi seumur hidup dan mengikuti asuransi berjangka dengan jangka waktu 25 tahun dengan menggunakan Tabel Mortalita Indonesia 1999.

Notasikan

$$
\begin{aligned}
x & =\text { Umur Arief }=40 \text { tahun, } \\
y & =\text { Umur Fitri }=35 \text { tahun, } \\
n & =\text { Jangka waktu mengikuti asuransi }=25 \text { tahun. } \\
R & =\text { Santunan yang diharapkan }=R p .100 .000 .000,-.
\end{aligned}
$$

(a) Kasus Arief meninggal dunia pertama

Tabel 1. Premi Arief meninggal pertama untuk dua orang tertanggung

\begin{tabular}{|c|c|c|}
\hline Premi & $\begin{array}{c}\text { Asuransi Kontingensi } \\
\text { Seumur hidup }\end{array}$ & $\begin{array}{c}\text { Asuransi Kontingensi } \\
\text { Berjangka }\end{array}$ \\
\hline Premi Tunggal bersih & $R p .33 .475 .960,22$ & $R p .12 .576 .155,62$ \\
\hline Premi Tahunan & $R p .1 .551 .145,39$ & $R p .719 .543,46$ \\
\hline
\end{tabular}

Dari tabel diatas dapat kita simpulkan ketika Arief mengikuti asuransi kontingensi seumur dan Arief meninggal pertama, maka premi tunggal bersih 
yang mereka bayarkan adalah sebesar $R p$. 33.475.960,22 dan premi tahunan sebesar $R p$. 1.551.145, 39 untuk besar santunan $R p$. 100.000.000,-. Sedangkan ketika Arief mengikuti asuransi kontingensi berjangka dengan jangka waktu 25 tahun maka mereka membayarkan premi tunggal bersih sebesar $R p .12 .576 .155,62$ dan premi tahunan sebesar $R p .719 .543,46$ untuk besar santunan $R p .100 .000 .000,-$.

(b) Kasus Arief meninggal dunia kedua

Tabel 2. Premi Arief meninggal kedua untuk dua orang tertanggung

\begin{tabular}{|c|c|c|}
\hline Premi & $\begin{array}{c}\text { Asuransi Kontingensi } \\
\text { Seumur hidup }\end{array}$ & $\begin{array}{c}\text { Asuransi Kontingensi } \\
\text { Berjangka }\end{array}$ \\
\hline Premi Tunggal bersih & $R p .10 .251 .874,93$ & $R p .526 .392,14$ \\
\hline Premi Tahunan & $R p .444 .528,48$ & $R p .29 .433,06$ \\
\hline
\end{tabular}

Dari tabel diatas dapat kita simpulkan ketika Arief mengikuti asuransi kontingensi seumur dan Arief meninggal kedua maka mereka membayarkan premi tunggal bersih sebesar $R p$. 10.251.874,93 dan premi tahunan sebesar $R p$. 444.528,48 untuk besar santunan $R p$. 100.000.000, - . Sedangkan ketika Arief mengikuti asuransi kontingensi berjangka dengan jangka waktu 25 tahun maka mereka membayarkan premi tunggal bersih sebesar $R p .526 .392,14$ dan premi tahunan sebesar Rp. 29.433, 06 untuk besar santunan $R p .100 .000 .000,-$.

\section{Ucapan Terima kasih}

Penulis mengucapkan terima kasih kepada Bapak Dr. Dodi Devianto, Ibu Dr. Ferra Yanuar, Ibu Dr. Lyra Yulianti, Bapak Yudiantri Asdi M.Sc dan Ibu Riri Lestari M.Si yang telah memberikan masukan dan saran sehingga paper ini dapat diselesaikan dengan baik.

\section{Daftar Pustaka}

[1] Futami, T. 1993. Matematika Asuransi Jiwa Bagian I. Tokyo: Incorporated Foundation Oriental Life Insurance Cultural Development Center.

[2] Futami, T. 1994. Matematika Asuransi Jiwa Bagian II. Tokyo: Incorporated Foundation Oriental Life Insurance Cultural Development Center.

[3] Jordan Jr, C.W. 1991. Society of Actuaries' Textbook on Life Contingencies, Second Edition. Chicago: The Society of Actuaris

[4] Larson, R.E. dan E.A.Gaumnitz. 1962. Life Insurance Mathematics. New York: John Wiley and Sons Inc

[5] Prowmislow, S. David. Fundamentals of Actuarial Mathematics. Second Edition. Canada : York University. 